\title{
COMPARISON OF THE CONDITIONS OF TAXATION ON LABOR IN HUNGARY AND THE SLOVAK REPUBLIC

\author{
Norbert Gyurián ${ }^{1}$, Ádám Szobi ${ }^{2}$, Nikoleta Nagyová ${ }^{3}$
}

\begin{abstract}
Income taxes constitute an important source of revenue for public finances everywhere. Essentially, the incomes of natural and legal persons are taxed. The tax on income from dependent activity, i.e. tax on labor, is one of the most important sources of tax revenue. The amount of tax revenue depends on the activities of the natural person (employee) but also on the activities of the persons who are in the position of the employer. These persons in the position of employer can also be natural persons, but in the majority of cases, they are legal persons. The focus of the study is on incomes from labor in Hungary and in Slovakia from the perspective of regulation and economic conditions. The main objective of the study is to examine the legislation on the taxation of labor and study the tax wedges in the two selected states. The conducted research is based on secondary sources. The results are presented in part in the results and discussion section and also in conclusion of the study. Our results point out the fact that even neighboring countries can have several differences in taxation with regard to the studied tax. One reason for studying this fact is that a good number of people in the bordering regions might extend their activities into the territory of the other country as well.
\end{abstract}

JEL Classification Numbers: H24, DOI: 10.12955/cbup.v7.1350

Keywords: Tax System, Taxes on Labor, Tax Base, Tax Wedges

\section{Introduction}

From a natural person's perspective, the income tax from dependent activities can be considered one of the most significant taxes. Each individual comes across taxation at some point in their life. In this paper, we focus on the taxation of the incomes of natural persons - employees. The majority of people are not well acquainted with the steps used to calculate the tax on labor; they simply accept the fact that it is inevitable to pay this tax and consider it their duty to do so.

Slovakia and Hungary have different taxation systems with regard to incomes from dependent activities. The differences can be observed both in the way the tax base is calculated and in the applicable tax rates. As a first step, we examine the applicable law and compare the laws in force in the two selected states. This is followed by an analysis of secondary data. In this analysis, we will focus not only on Hungary and Slovakia, but also on other EU member states, like the Czech Republic, Poland, Germany and Portugal.

\section{Literature review}

Taxation is traditionally conceived of as the sector of the public law through which governments raise revenue needed for their justifiable distributive aims. The rules of tax law, in this view, control the manner in which governments raise revenue, while rules of transfer guide government spending (Paul et al., 2006).

Bojňanský (2013) defines the concept of taxes from a legal and a financial and economic perspective. From a legal perspective, he considers taxes to be obligatory, non-refundable, non-equivalent and nonspecific payments that are made into the state budgets by means of predefined rules. The financial and economic definition of taxes emphasizes the relation between the taxpayer and the state budget.

The aim of the individual income tax is to collect the individuals' contributions to the public expenses and to guarantee tax revenue for the state and local government budgets (Sztanó and Kis, 2013).

Bencsik (2011) regards the payment of taxes to be an obligation in exchange for which we do not get any direct compensation, but the state compensates us indirectly through spending the taxes on the basic needs of society.

Under the individual income tax act, the legal requirement to pay taxes arises from the day of commencement of the activities yielding an income, or the day of commencement of the legal relationship from which an income arises (Sztanó and Kis, 2013; Bozsik et al., 2011).

The requirement to pay a tax is levied on the taxpayer by the state or other public authority in accordance with the law whereby the amount or rate of the tax, its conditions and maturity date are

\footnotetext{
${ }^{1}$ Faculty of Economics, J. Selye University, Komárno, Slovakia ngyurian@gmail.com

${ }^{2}$ Faculty of Economics, J. Selye University, Komárno, Slovakia, szobi.adam@gmail.com

${ }^{3}$ Faculty of Economics, J. Selye University, Komárno, Slovakia, nikoleta.nagyova7@gmail.com
} 
defined; taxes are widespread, non-returnable and non-profitable material contributions (Herich, 2017).

Tax is a revenue to the Government. The Government can generate revenue through various sources. These sources may be Direct or Indirect. Income tax is a direct tax to the treasury. It is one of the most important sources of revenue to the Government. In a socialistic pattern of society, it is the duty of the Government to bring out various welfare and development programs and measures in order to match the requirements of the rich and the poor. For this purpose, the Government needs money. Money can be raised from various sources. Income tax is one such source through which the Government can mobilize funds (Hariharan, 2017).

\section{Data and methodology}

The main objective of our study is to analyze and compare the taxation of labor income in the territory of Slovakia and Hungary. In order to achieve our objective, we examined the legislation regarding the studied tax and then processed secondary data. In the process of compiling this study, we have processed domestic and foreign literature. We have also drawn from statistical publications of the European Union. We have presented the theory regarding the methodology of the taxation of labor in Hungary and also in Slovakia. On an empirical level, we have evaluated the significance of the tax on labor from the perspective of the state budgets. We also paid attention to the revenue from tax on labor as a ratio of the GDP of the individual states and as a ratio of their total revenues. Last, but not least, we assessed the level of the tax burden on individuals with regard to incomes from dependent activities.

\section{Legal background of the tax on labor in Hungary and in Slovakia}

Under Slovakian law, all natural persons who had attained taxable income are subject to the individual income tax. The individual income tax is regulated in the territory of the Slovak Republic by Act No 595/2003 on the Income Tax and the Amendment of Certain Acts as amended (Income Tax Code).

Incomes from dependent activities are regulated by Section 5 of the Income Tax Code. The peculiarities of the taxation of incomes falling into this category manifest themselves mainly in the tax allowances and tax credits (sometimes referred to as tax bonuses) that can be claimed.

The revenue of an individual from dependent activities arises from an existing legal relationship in which they figure as the employee. All revenues attained by the individual with relation to these activities or based on the legal relationship underlying these activities fall into this category. Incomes attained as wages and salaries, fees, bonuses, reimbursements, fuel savings specifically fall into this category.

A tax allowance is a sum which can under no circumstances constitute part of the tax base. The amount of tax allowance is regulated by Section 11 of the Act. The Act provides for the following tax allowances:

a) tax allowance pertaining to the taxpayer,

b) tax allowance pertaining to the spouse,

c) tax allowance for the promotion of voluntary contributions to old-age pension savings,

d) tax allowance for recreation.

The tax allowance pertaining to the taxpayer is the most significant of all the tax allowances. For this reason, we will focus our attention mostly on this item. This tax allowance is considered in the calculation of an individual's monthly tax advances and in his annual tax clearing. A condition of claiming this tax allowance is that the taxpayer has not yet reached retirement age.

The subsistence minimum applicable at the beginning of a given tax year is to be taken into account when calculating the amount of the tax allowance pertaining to the taxpayer. Further changes in the subsistence minimum are not considered during that tax year. The first step in the calculation of the amount of tax allowance an individual can claim involves establishing whether the revenue of said individual (already reduced by the above mentioned contributions the individual has paid):

- is equal to or lower than 100 times the applicable subsistence minimum - in this case the taxpayer may claim a lump sum tax allowance in the amount corresponding to 19.2 times the applicable subsistence minimum, 
- is higher than 100 times the applicable subsistence minimum - in this case the taxpayer may claim a tax allowance in a variable amount corresponding to the difference between 44.2 times the applicable subsistence minimum and one quarter of his tax base.

The tax allowance for the promotion of voluntary contributions to old-age pension savings and the tax allowance for recreation are considered to be less significant tax incentives. In the tax years 2018 and 2019, a tax allowance for the promotion of voluntary contributions to old-age pension savings can be claimed in the amount of EUR 180. The tax allowance for recreation is in the sum of EUR 50 pertaining to the taxpayer and to his spouse and children.

Another peculiarity of the individual income tax system in Slovakia is the tax bonus. In contrast to the tax allowances, it is deductible not from the tax base, but from the payable tax. There are two types of tax bonus:

- tax bonus for maintained children,

- tax bonus for mortgage interests.

A tax bonus for maintained children can be claimed for each dependent child the individual is maintaining, either on an annual or a monthly basis. An important rule is that a tax bonus pertaining to any given child can only be claimed by one of the parents. To claim a tax bonus, the following conditions also need to be met:

- the income of the taxpayer needs to be equal to not less than six times the minimum wage applicable in the given tax year,

- the individual needs to be able to provide proof that he is indeed maintaining the child pertaining to whom he is claiming a tax bonus and they need to live in the same household.

With regard to the tax bonus for maintained children, changes in the course of a tax year are frequent. If a change occurs, it is important to take it into account. This element is therefore different from the methodology how the subsistence minimum is taken into account, because, in that case, only the state of affairs applicable 1 January needs to be considered.

Taxpayers are eligible to claim a tax bonus in its full amount in the month their child is born up until the month the child reaches the age of 25. Table 6 shows the applicable basic amounts of the tax bonus in 2018 and 2019. A new change is enacted as of 1 April 2019 which provides that a tax bonus in an amount of EUR 44.34 can be claimed for children under six years of age.

Individuals can claim a tax bonus for mortgage interests for the first time in 2018. It can be claimed on an annual basis. It is focused on individuals between the age of 18 and 35 whose income does not exceed 1.3 times the average wage in the territory of Slovakia. The maximum amount of tax bonus for mortgage interests that can be claimed is equal to $50 \%$ of the interest paid by the individual but, cannot exceed an annual maximum amount of EUR 400.

Section 15 of the Income Tax Code regulates the individual income tax rates. There is a progressive individual income tax rate structure in effect in the territory of the Slovak Republic. The progressivity is represented by the two tax rates (19\% and 25\%). The threshold between the two tax brackets is set at 176.8 times the subsistence minimum. If the tax base of the taxpayer exceeds this threshold, their taxes will be calculated using both tax rates. With regard to individual income tax, the Act also provides for two more tax rates at $7 \%$ and $35 \%$, respectively. These tax rates can be applied to the incomes of Slovakian individuals attained abroad and incomes of foreign individuals attained in the territory of Slovakia in cases where there is no treaty regulating international taxation.

The calculation of the tax base of individuals from labor income in the territory of the Slovak Republic:

Total gross income

- Contributions (deducted from the wage/salary)

Partial tax base

- Tax allowances

Adjusted tax base

$\mathrm{x}$ Tax rate $(19 \%, 25 \%)$

$=$ Calculated tax

- Tax bonus 
$=$ Tax payable

- Deducted tax advances, taxes

$=$ Tax to be paid

Act CXVII of 1995 on the Individual Income Tax defines two main types of income in Hungary. In these two main types of income, further income divisions, groups and subgroups are defined:

- the consolidated tax base (this includes incomes from independent activities, incomes from dependent activities and other incomes)

- incomes which are to be declared and taxed separately (this includes the taxation of private entrepreneurs, the transfer of assets, incomes from capital investments, in-kind benefits and other allowances, miscellaneous incomes and valuable considerations obtained in the form of securities or by way of rights in securities).

Income from dependent activities includes all income earned by an individual in connection with such activities or in consequence of any legal relationship underlying such activities. Included are, in particular, wages, remuneration, honoraria and any sums received as bonuses or expense reimbursement paid by others pertaining to the dependent activities. In respect of incomes from dependent activities, the option of writing off expenses is usually not available (www.eji.hu, online, 2019).

The consolidated tax base includes all income earned by an individual from independent activities and from dependent activities, as well as other income, in respect of - but only up to - which and in some cases in respect of - but only up to - the tax on which tax incentives and tax exemptions can be claimed.

In the case of incomes included in the consolidated tax base, the individual income tax base is the amount of gross income increased by an amount calculated using the basic rate of the social security contribution tax payable by the employer. This means that in the case of incomes included in the consolidated tax base, 19.5 per cent of such income needs to be added as an item increasing the tax base. The consolidated tax base includes all income attained by an individual from independent activities and from dependent activities, as well as incomes calculated from other revenue. The family tax allowance can be deducted from the tax base, thus reducing the individual income tax liability.

From the calculated tax, currently the below mentioned kinds of tax credit can be deducted. These are the following:

- extended tax credit for housing loan repayments,

- a personal tax credit - in the sum of 5 per cent of the applicable minimum wage. Persons receiving disability benefits, that is severely handicapped people can claim this tax credit,

- small-scale agricultural producers' tax credit - in the sum of HUF 100,000. Individuals with a small-scale producer license can claim it if their revenue from crop cultivation and animal husbandry is more than HUF 600,000 but does not reach HUF 8 million,

- voluntary contributions to old-age pension savings $-20 \%$ of such contribution but no more than HUF 130,000 can be deducted from the calculated tax,

- miscellaneous (postponed tax credits claimed for education costs, adult training) - in many regards akin to the tax credit for housing loan repayments.

The calculation of the tax base of individuals from labor income in the territory of Hungary:

Gross revenues

- Items which do not count as revenue

- Costs

$=$ Taxable income

- Family tax allowance

$=$ Tax base

$\mathrm{x}$ Tax rate $(15 \%)$

$=$ Calculated tax

- Tax credits

+ Tax credits to be repaid

$=$ Tax payable 
- Deducted tax advances, taxes

$=$ Tax to be paid

\section{Tax revenues from tax on labor}

As mentioned earlier, tax on labor plays a vital role as a source of state revenue. We seek to provide evidence for this fact in this part of our paper. First, we compare the total revenue from tax on labor to the GDP of the studied countries. We will focus our attention on Hungary and Slovakia and several other EU member states such as the Czech Republic, Poland, Germany, Sweden and Portugal.

\begin{tabular}{|c|c|c|c|c|c|c|c|c|c|c|c|c|c|c|c|}
\hline & 2004 & 2005 & 2006 & 2007 & 2008 & 2009 & 2010 & 2011 & 2012 & 2013 & 2014 & 2015 & 2016 & $\begin{array}{c}\text { Difference } \\
(1) \\
2006 \text { to } \\
2016\end{array}$ & $\begin{array}{c}\text { Revenue } \\
\text { (2) } \\
2016\end{array}$ \\
\hline EU-28 & 18,7 & 18,6 & 18,5 & 18,4 & 18,8 & 19,2 & 19,1 & 19,1 & 19,4 & 19,6 & 19,4 & 19,1 & 19,3 & 0,9 & 2883683 \\
\hline EA-19 & 19,8 & 19,7 & 19,6 & 19,5 & 19,9 & 20,5 & 20,3 & 20,4 & 20,9 & 21,1 & 21,1 & 20,9 & 20,9 & 1,3 & 2252876 \\
\hline SK & 15,5 & 15,0 & 14,1 & 14,0 & 14,4 & 15,0 & 14,6 & 14,8 & 15,1 & 16,1 & 16,2 & 16,7 & 17,2 & 3,1 & 13968 \\
\hline $\mathrm{HU}$ & 17,5 & 17,7 & 17,8 & 19,4 & 20,1 & 18,6 & 17,4 & 17,1 & 17,6 & 17,4 & 17,4 & 17,6 & 18,1 & 0,3 & 20614 \\
\hline $\mathrm{CZ}$ & 17,5 & 17,4 & 17,5 & 17,7 & 17,2 & 16,2 & 16,7 & 17,0 & 17,1 & 17,3 & 17,2 & 16,9 & 17,4 & $-0,1$ & 30724 \\
\hline PL & 12,9 & 13,0 & 13,0 & 12,4 & 12,4 & 12,0 & 11,8 & 12,0 & 12,6 & 12,6 & 12,8 & 13,1 & 13,3 & 0,3 & 56741 \\
\hline $\mathrm{DE}$ & 21,9 & 21,4 & 21,2 & 20,6 & 21,1 & 21,8 & 21,0 & 20,9 & 21,4 & 21,6 & 21,6 & 21,8 & 22,0 & 0,9 & 692323 \\
\hline SW & 28,1 & 27,7 & 27,0 & 25,9 & 26,3 & 25,9 & 24,5 & 24,5 & 25,2 & 25,4 & 25,0 & 24,8 & 25,7 & $-1,3$ & 119443 \\
\hline PT & 11,9 & 12,1 & 12,1 & 12,2 & 12,4 & 12,7 & 12,5 & 13,3 & 12,7 & 14,7 & 14,8 & 14,8 & 14,5 & 2,4 & 26889 \\
\hline
\end{tabular}

Table 1 shows that in the case Germany and Sweden, the revenues from tax on labor make up a higher percentage of the GDP. These states show values that are above average. The opposite can be observed in the case of the remaining studied states. EUR 2,883,683 million of tax revenue was collected from tax on labor in the 28 European Union member states in 2016. This figure illustrates the significance of the studied tax. From the studied states, Germany has the biggest share on this sum with its EUR 692,323 million of collected revenues from tax on labor in 2016. The smallest value can be observed in the case of Slovakia in the sum of EUR 13,968 million.

\begin{tabular}{|c|c|c|c|c|c|c|c|c|c|c|c|c|c|c|c|}
\hline & 2004 & 2005 & 2006 & 2007 & 2008 & 2009 & 2010 & 2011 & 2012 & 2013 & 2014 & 2015 & 2016 & $\begin{array}{c}\text { Difference } \\
(1) \\
2006 \text { to } \\
2016\end{array}$ & $\begin{array}{c}\text { Revenue } \\
\text { (2) } \\
2016\end{array}$ \\
\hline EU-28 & 50,1 & 49,4 & 48,8 & $\begin{array}{ll}48,4 \\
\end{array}$ & 49,8 & 51,9 & 51,2 & 50,8 & 50,6 & 50,5 & 50,3 & 49,7 & 49,8 & 1,0 & 2883683 \\
\hline EA-19 & 52,1 & 51,5 & 50,7 & 50,3 & 51,9 & 53,9 & 53,5 & 53,1 & 52,9 & 52,7 & 52,6 & 52,3 & 52,1 & 1,4 & 2252876 \\
\hline SK & 48,9 & 47,9 & 48,2 & 48,1 & 49,6 & 52,3 & 52,2 & 51,8 & 53,6 & 53,3 & 52,3 & 52,2 & 53,4 & 5,3 & 13968 \\
\hline $\mathrm{HU}$ & 47,5 & 48,6 & 48,8 & 49,3 & 51,0 & 47,9 & 46,7 & 46,8 & 46,0 & 46,0 & 45,6 & 45,4 & 46,1 & $-2,7$ & 20614 \\
\hline $\mathrm{CZ}$ & 50,6 & 50,9 & 51,6 & 51,2 & 51,8 & 50,3 & 51,3 & 50,4 & 50,0 & 49,6 & 50,9 & 49,5 & 50,1 & $-1,5$ & 30724 \\
\hline PL & 40,5 & 39,4 & 38,6 & 35,9 & 36,3 & 38,3 & 37,7 & 37,8 & 39,2 & 39,4 & 40,1 & 40,3 & 39,9 & 1,3 & 56741 \\
\hline $\mathrm{DE}$ & 59,2 & 57,9 & 56,8 & 55,0 & 55,9 & 57,5 & 57,1 & 56,1 & 56,5 & 56,5 & 56,6 & 56,6 & 56,5 & $-0,2$ & 692323 \\
\hline SW & 61,5 & 59,5 & 58,8 & 57,6 & 59,7 & 58,8 & 56,8 & 57,7 & 59,2 & 59,1 & 58,6 & 57,6 & 58,3 & $-0,5$ & 119443 \\
\hline PT & 39,5 & 39,2 & 38,6 & 38,2 & 39,0 & 42,5 & 41,2 & 41,0 & 39,9 & 43,1 & 43,3 & 42,9 & 42,2 & 3,7 & 26889 \\
\hline
\end{tabular}

Table 2 shows the ratio at which the tax on labor contributed to total tax revenues in the studied states. The highest tax on labor to total tax revenue ratio can be observed in Sweden. This highest value applies to the year 2004. Following this year, the observed values are lower, but still close to $60 \%$. The lowest values can be observed in the case of Portugal and Poland. The indicator in question shows an average value of around 50\% with respect to the 28 European Union member states. The largest increase in the values can be observed in the case of Slovakia. This studied state shows a nearly 5.3 percentage point increase between 2006 and 2016. On the other hand, the largest decrease is connected to Hungary. The mentioned state has seen a decrease of 2.7 percentage points.

Table 3 contains the values pertaining to the tax wedges for persons in an employment relationship. The cited figures pertain to such natural persons who have been earning $50 \%$ of the given state's average wage and have not claimed tax credits with regard to their children. This indicator shows a value of about 33 points with respect to the 28 European Union member states. Values near this 
average can be observed in the case of Slovakia and Poland. Portugal shows values below the average. In the case of the other studied states, significantly higher values are shown.

\begin{tabular}{|c|c|c|c|c|c|c|c|c|c|c|c|c|}
\hline & 2006 & 2007 & 2008 & 2009 & 2010 & 2011 & 2012 & 2013 & 2014 & 2015 & 2016 & $\begin{array}{l}\text { Difference } \\
\text { 2006-2016 } \\
\end{array}$ \\
\hline EU-28 & 32,7 & 32,8 & 33,5 & 33,0 & 33,2 & 33,8 & 34,0 & 33,8 & 33,5 & 33,1 & 32,5 & $-0,2$ \\
\hline EA-19 & 31,4 & 31,5 & 32,3 & 31,9 & 32,3 & 33,0 & 33,2 & 33,0 & 32,6 & 32,0 & 31,2 & $-0,2$ \\
\hline SK & 32,2 & 32,5 & 33,3 & 31,0 & 31,4 & 33,2 & 34,1 & 35,7 & 36,0 & 31,9 & 32,6 & 0,4 \\
\hline $\mathrm{HU}$ & 40,1 & 43,1 & 43,4 & 42,7 & 41,0 & 43,1 & 45,4 & 48,2 & 49,0 & 49,0 & 48,2 & 8,1 \\
\hline $\mathrm{CZ}$ & 38,4 & 38,7 & 36,7 & 35,4 & 35,7 & 36,6 & 36,3 & 36,3 & 36,6 & 37,0 & 37,3 & $-1,0$ \\
\hline PL & 36,7 & 36,0 & 32,5 & 32,1 & 32,3 & 32,5 & 33,8 & 33,9 & 34,1 & 34,3 & 34,4 & $-2,4$ \\
\hline $\mathrm{DE}$ & 43,8 & 43,3 & 42,9 & 42,2 & 41,7 & 42,4 & 42,4 & 42,0 & 41,9 & 42,1 & 42,2 & $-1,6$ \\
\hline SW & 44,4 & 41,6 & 40,9 & 39,6 & 39,0 & 39,1 & 39,1 & 39,3 & 38,8 & 39,0 & 39,2 & $-5,2$ \\
\hline PT & 30,5 & 30,5 & 30,1 & 28,1 & 28,1 & 28,1 & 28,1 & 28,1 & 28,1 & 28,1 & 28,1 & $-2,4$ \\
\hline
\end{tabular}

Source: European Commission tax and benefits indicator database based on OECD Tax-benefit Model

\section{Conclusion}

Having analyzed the taxation of labor in Hungary and in Slovakia, we can conclude that there are substantial differences in the methodology of the calculation of the tax on labor. These differences can be observed both in the calculation of the tax base and in the tax rates.

The following differences can be observed regarding the tax base:

- differences in the way the concept of income is defined/calculated,

- in the way social security payments are accounted for,

- the amount and application of tax incentives.

The tax rate is linear at $15 \%$ in Hungary; in contrast, Slovakia has a progressive two-rate income tax system with a $19 \%$ and a $25 \%$ tax rate.

The secondary data we have studied show that the tax on labor is a very important tax from the perspective of state budget revenues. EUR 2,883,683 million of tax revenue was collected from tax on labor in the 28 European Union member states in 2016. This is a very decisive fact, one that motivates each and every European Union member state to devote due attention to the tax on labor.

\section{Acknowledgments}

This study was supported by the Pallas Athéné Domus Educationis Foundation.

\section{References}

Bencsik, M. (2011). Adózás alapjai [The Basics of Taxation], electronic textbook. Budapest.

Bojňanský, J. et al. (2017). Dane podnikatel'ských subjektov [Taxes of Business Entities], Slovenská pol'nohospodárska univerzita v Nitre [Slovak University of Agriculture in Nitra].

Bozsik S., Fellegi, M., Gróf, P. Süveges, G., Szemán, J. (2011). Haladó vállalati pénzügyek. Publisher: Miskolci Egyetem [University of Miskolc].

Paul, E. F, Miller, F. D., Paul, J. (2006) Taxation, Economic Prosperity, and Distributive Justice. Cambridge University Press.

Hariharan, N. (2017). Income Tax Law \& Practice. Publisher: MCGRAW-HILL EDUCATION (INDIA).

Herich, Gy. (2017). Adótan [On Taxes]. Budapest: PENTA UNIÓ Zrt.

Személyi jövedelemadó [Individual Income Tax]. (2019). Retrieved from https://www.eji.hu/cikkek/cikk/szemelyi_jovedelemado.html.

Sztanó, I., Kis, T. (2013) Adózás, társadalombiztosítás, támogatás [Taxation, Social Security, Subsidies] [online]. Digitális Tankönyvtár [Digital Textbook Repository]. Retrieved from http://www.tankonyvtar.hu/hu/tartalom/tamop412A/0007_d6_1100_1101_1103_adozas_tb_scorm/adatok.html. 